\title{
Partial Pressure
}

National Cancer Institute

\section{Source}

National Cancer Institute. Partial Pressure. NCI Thesaurus. Code C75755.

The pressure exerted by a single component of a mixture of gases. 